\title{
Basic Research Versus Export Controls
}

\author{
Paul R. Betten
}

Every few years the debate between the freedom to disseminate basic research advances and the regulatory aspects of export control is revisited. The debate never seems to be resolved. Enough discussion occurs, however, to allow both sides to claim a marginal victory and see the issue disappear for a few more years. Although the issue cannot be resolved here, some of the key points can be related along with a few added insights from the technology transfer perspective.

The major concern is how one maintains control and use of technological advances in a free society. It is enmeshed with developing concerns about U.S. competitiveness in a global marketplace. A parallel debate centers on whether U.S. research and development ideas have been appropriated by overseas industry or whether U.S. businesses have been too complacent about capitalizing on their own R\&D advances.

Export controls are justified on three bases: national security, foreign policy, and limited domestic supply. Controls include various commodity restrictions that depend on the country involved. But, technical data may also be restricted-and the debate centers here.

Technical data are defined broadly and include installation, operations, maintenance, and repair manuals; blueprints or manufacturing specifications; and software (including mass-marketed software). Although export control is commonly thought of in terms of hardware, controlling technical data release can be a greater problem because data are easy to conceal, usually not immediately missed, and easily transmitted by mail, fax or electronic means. Data provide immediate access to results without the need to reverseengineer the corresponding hardware. Recovery of data is moot once the content has been learned by the competition.

Technical data restrictions also require scrutiny of the access afforded visitors from overseas. Some may feel that export control concerns are exaggerated, especially where data appear far removed from practical application. We must remind ourselves that export controls are law, actively enforced, the violation of which carries both criminal and civil penalties. Indeed, hundreds of seizures are made every year by the Customs Service and Export Enforcement Office. Most such instances involve tangible hardware. But in the case of personal computers, for example, the inclusion of associated software illustrates how blurred the distinction between hardware and data can be.

The value of basic
technical data to
whoever receives it
really depends on their
willingness to invest in
development and
to take a risk.

It is clear, however, that national security hardware concerns are very real. A case in point is the sale several years ago of advanced machining equipment by a Japanbased industry to the Soviet Union, which enabled significantly reduced submarine propeller noise. That cost the U.S. taxpayer millions of dollars for countermeasures and corresponding R\&D. The concerns about technical data are just as real but are more complicated and diffuse because of the intrinsic nature of data. Are basic R\&D data as sensitive as proprietary or manufacturing data? Basic data are generally not of immediate use because time and funding are needed to develop them.

Dual-use technologies, i.e., those with both peaceful and military uses, can pose vexing control problems because both the technology and end-use may appear benign. Supercomputers, parallel computers, certain types of fuel cells or batteries, and certain types of material or manufacturing techniques at first appear unrelated to military applications. Countries clearly can have legitimate (that is, benign) uses for dual-use technologies. The same technology that launches a satellite can launch a missile. Indeed, international cooperation under treaty can require dualuse items. Personal computers with the latest integrated circuits can be used to monitor global warming conditions, for example, but are militarily restricted items.

Research organizations argue that their basic research efforts, supported by taxpayers, should be shared by all-a view consistent with a free and open society. To restrict publishing the results of those efforts would withhold information from the public, and would encumber the system and suppress the creativity that produced it. Furthermore, from a practical standpoint it is argued that there are already too many regulations and requirements, and that full implementation of an export control system would add bureaucracy and cost in an already complex and fiscally tight situation.

The claim is made that export controls cannot be practically applied without shutting down universities, because they rely heavily on talent from overseas. This exaggeration neglects the many countries of origin and residency statuses to which controls don't apply. Nevertheless, some research or technology areas may be restricted and may be export sensitive. If an Eastern Bloc national is doing research on supercomputers in the United States, there could be a serious problem. (That many foreign students educated in the United States remain there to contribute greatly to U.S. R\&D is often overlooked.) Whether you believe overseas competitors have usurped U.S. R\&D ideas or simply that U.S. firms have failed to capitalize on their own research, it is a myth that basic science discoveries merely trickle down to commercialization. Many basic scientific successes have been commercial failures. U.S. defense expenditures in the technology base for FY 1990 indicate that fundamental and exploratory research account for only $2 \%$ and $6 \%$, respectively, of the entire technology base budget. The remainder goes primarily into engineering and design, manufacturing, and testing and evaluation. Thus even in the defense arena, enormous funding and manpower are needed before the fruits of basic research can be practically realized. The value of basic technical data to whoever receives it really depends on their willingness to invest in development and to take a risk.

The United States is no longer the leader in many R\&D areas. Advances or 
component/system availability abroad leave many export controls outdated and counterproductive. U.S. expertise would benefit from increased international interactions in those areas. Japan's computer chip manufacturing, Europe's high-speed train technology, Japan's and Germany's recent advances in levitated trains, the Soviet Union's experience in compact storage rings and diamond films, and several nations' superconductivity advances-all exemplify areas where the United States would do well to strongly interact. The onus to determine whether $R \& D$ data are basic or restricted generally lies with individual researchers, their organizations, and their funding sources. Individual researchers are closest to the R\&D and can probably best determine classification. Thus prevailing mindsets must be changed and, in essence, the regulatory process must be institutionalized. Staff education is very important. Researchers or research managers should have some knowledge of classification issues, a reference book, or someone to call so they can make informed decisions.

It would be prudent for organizations to review their export control process. Items to consider and examine are an export control compliance manual, internal export control checks, continuing staff education, typical export licenses used, and coordination of controls within the organization. Usually these matters are handled by a shipping department which may not be adequately trained. This aspect is easily remedied with sufficient management training and may protect an organization from future costs, liabilities, and penalties while leaving the tasks of informed judgments in the "fuzzy" areas in the hands of those most affected by under- or overzealous enforcement.

Debate between export restrictions and basic research publication is by no means resolved and will continue for several years. However, the increasingly global nature of the economy, the relaxation of geopolitical tension between East and West, and the inherent vagueness and difficulty in controlling the dissemination of technical data portend a trend toward fewer restrictions on basic research data and an overall lessening of export control regulations.

Paul R. Betten is the director of the Office of Research and Technology Assessment at Argonne National Labomtony. Serving in this position, he is involved with many aspects of technology transfer.

\section{Membership in the Materials Research Society}

The Materials Research Society is an organization of scientists. Membership is open to those interested in materials properties, development, processing, or characterization. Membership benefits for regular members include:

- A subscription to Journal of Materials Research, an archival interdisciplinary journal which is the official journal of the Materials Research Society.

- A subscription to the MRS Bulletin, a monthly news publication which contains summaries of Society symposia, news of Society members, announcements of meetings and other activities of interest to members, reports about developments in research and industry, and editorial and feature articles covering research and policy matters affecting the materials community.

- Call for papers and preliminary program booklets for both the Spring and Fall meetings.

- A listing in and copy of the MRS Membership Directory.

- MRS symposium proceedings at discounts of $15-25 \%$. Reduced rates for publications from other scientific organizations and publishers, including the American Institute of Physics.

- Voting rights in the annual election of MRS Officers and Councillors. 